\title{
Is access to care different for women from sub-Saharan Africa than for French women according to prevention of mother-to-child HIV transmission in France?
}

\author{
Carine Jasseron*1,2, Josiane Warszawski ${ }^{1,2,3,4}$, Stéphane Blanche ${ }^{5,6}$, \\ Christine Rouzioux ${ }^{6,7}$, Jérôme Le Chenadec ${ }^{2,4}$, Catherine Dollfus ${ }^{8}$, \\ Albert Faye ${ }^{9}$, Karima Hamrene ${ }^{1,2}$, Jean-Paul Teglas ${ }^{2,4}$, Roland Tubiana10,11, \\ Laurent Mandelbrot ${ }^{1,12,13}$ and ANRS French Perinatal Cohort EPF
}

\begin{abstract}
Address: ${ }^{1}$ Inserm, U822, Le Kremlin-Bicêtre, France, F-94276, ${ }^{2}$ AP-HP, Epidemiology department, Hopital Bicêtre, Le Kremlin-Bicêtre, France, F94276, ${ }^{3}$ Univ Paris-Sud, Faculté de Médecine Paris-Sud, Le Kremlin-Bicêtre, France, F-94276, ${ }^{4}$ INED, Paris, France, F-75020, ${ }^{5}$ AP-HP, Unité d'Immunologie Hématologie Pédiatrique, Necker Hospital, Paris, France, F-75015, ${ }^{6}$ EA 3620, Univ Paris Descartes 5, Paris, France, 7 AP-HP, Virology Department, Necker Hospital, Paris, F-75015 France, ${ }^{8}$ AP-HP, Service d'Hématologie et d'oncologie pédiatrique, Hôpital Trousseau Paris, F-75571 France, ${ }^{9}$ AP-HP, Service de Pédiatrie Générale, Hôpital Robert Debré,Paris, F-75019 France, ${ }^{10}$ AP-HP, Department of infectious diseases, Hôpital Pitié Salpêtrière, Paris, F-75651 France, ${ }^{11}$ INSERM, U543, Paris, France, ${ }^{12}$ Univ Paris 7, Paris, France and ${ }^{13}$ AP-HP, Gynecology and obstetrics department, Hôpital Louis Mourrier, Colombes, France, F-92700

* Corresponding author
\end{abstract}

from Fourth Dominique Dormont International Conference. Host-Pathogen Interactions in Chronic Infections Paris, France. 13-15 December 2007

Published: 9 April 2008

Retrovirology 2008, 5(Suppl I):OI6 doi:10.1I86/I742-4690-5-SI-OI6

This abstract is available from: http://www.retrovirology.com/content/5/SI/OI6

(C) 2008 Jasseron et al.; licensee BioMed Central Ltd.

\section{Background}

Among HIV-infected women delivering in France, two thirds are immigrants from sub-Saharan Africa. A high proportion of immigrants live in precarious conditions $[1,2]$, which may be a potential obstacle to adequate prevention of HIV Mother-to-child transmission (MTCT) We aimed to compare indicators of access to prevention of MTCT between African and French-born women.

\section{Materials and methods}

We used data from the French Perinatal HIV Cohort (EPF), a multicenter prospective cohort of HIV-infected pregnant women and their children. Women enrolled in EPF were included in our analysis if they were infected by HIV-1, and delivered in mainland maternities from 1985 to 2004: 9245 pregnancies in 7090 mothers (3292 from sub-Saharan Africa and 2766 from mainland France).

\section{Results}

Compared with French women, African women had later access to care, whatever the study period. During the
HAART era period, a higher proportion of African women discovered their HIV infection during pregnancy $(6.8 \%$ vs $1.2 \%$ after 28 weeks, respectively), started prenatal care in the third trimester (14.1\% vs $9.8 \%$ ) and started antiretroviral treatment late, after 33 weeks $(7.6 \%$ vs $4.1 \%)$. The association with late treatment initiation disappeared when adjusting for the time of HIV diagnosis and first prenatal visit (adjusted OR: 1.0 ; 95\%CI : 0.8-1.5). Geographic origin was not associated with management in contradiction with French recommendations, such as monotherapy or vaginal delivery with uncontrolled delivery viral load, lack of intrapartum and postpartum treatment or breastfeeding. Highly active antiretroviral therapy during pregnancy was as frequently used in African and in French women.

\section{Conclusion}

African women had a higher proportion of late HIV screening in pregnancy than French women, but access to MTCT prevention, once the infection was diagnosed was similar in those two groups. 


\section{Acknowledgements}

The study was supported by the ANRS. We thank all cohort investigators and $\mathrm{V}$ Benhammou, Y Benmebarek, N Chernai, A Diop, P Huynh, C Laurent, M Peres, E Ramos, L Boufassa, T Wack, N Zeller.

\section{References}

I. Dray-Spira R, Lert F, Marimoutou C, Bouhnik AD, Obadia Y: Socioeconomic conditions, health status and employment among persons living with HIVIAIDS in France in 200I. AIDS Care 2003, I 15:739-748.

2. Chee CC, Mortier E, Dupont C, Bloch M, Simonpoli AM, Rouveix E: Medical and social differences between French and migrant patients consulting for the first time for HIV infection. AIDS Care 2005, 17:516-520.

Publish with Bio Med Central and every scientist can read your work free of charge

"BioMed Central will be the most significant development for disseminating the results of biomedical research in our lifetime. "

Sir Paul Nurse, Cancer Research UK

Your research papers will be:

- available free of charge to the entire biomedical community

- peer reviewed and published immediately upon acceptance

- cited in PubMed and archived on PubMed Central

- yours - you keep the copyright

Submit your manuscript here:

http://www.biomedcentral.com/info/publishing_adv.asp 